\title{
Non-association between anti-Toxoplasma gondii antibodies and ABO blood group system
}

Rodrigues ACF (1), Uezato S (1), Vono MB (1), Pandossio T (1), Spegiorin LCJF (2), Oliani AH (2), Vaz Oliani DCM (2), Brandão de Mattos CC (1), de Mattos LC (1)

(1) Laboratory of Immunogenetics, Department of Molecular Biology, Medical School of São José do Rio Preto, FAMERP, São José do Rio Preto, São Paulo State, Brazil; (2) Department of Gynecology and Obstetrics, Medical School of São José do Rio Preto, FAMERP, and Base Hospital, FUNFARME, São José do Rio Preto, São Paulo State, Brazil.

\begin{abstract}
Toxoplasma gondii infects humans through the gastrointestinal tract (GIT), which elicits humoral immune response with specific antibodies. The expression of the ABO blood group glycoconjugates also occurs in this same system and may influence the human susceptibility of infection by T. gondii. The aim of the present study was to investigate the association between ABO blood group phenotypes and the presence of anti-T. gondii antibodies. Data - including age, results of serology tests for T. gondii infection and $A B O$ blood group phenotypes - were assembled from the medical records of 1,006 pregnant women attended in the Base Hospital of the Medical School of São José do Rio Preto, Brazil, between 2001 and 2004. The chi-square test was used to compare the results with the level of significance set at $5 \%$. Of the studied cases, $64.1 \%$ (645/1006) and 35.9\% (391/1006) presented respectively positive and negative serology tests for anti-T. gondii antibodies. The mean age of those who tested positive was higher than those with negative serology tests $(p=0.0004)$. The frequencies of $A B O$ blood group phenotypes were similar in those with and without anti-T. gondii antibodies $(p=0.35)$. In conclusion, the ABO blood group system is not associated with the presence or absence of anti-T. gondii antibodies.
\end{abstract}

Key words: human blood groups, Toxoplasma gondii, toxoplasmosis, ABO blood group, pregnant women.

\section{INTRODUCTION}

Some microorganisms adhere to glycoconjugates (glycoproteins and glycolipids) expressed in the epithelial cells of the mucous membranes of hosts, since these molecules act as potential receptors $(1,2)$. The molecules that define $\mathrm{ABO}$ blood group phenotypes consist of carbohydrates that are present in the structures of glycoproteins and glycolipids expressed in red blood cells and other tissues (3). The adherence mechanism of microorganisms to mucous membranes of hosts is not totally clear, but it is likely that glycoconjugates of the ABO blood group system are involved in this process (4).

Previous studies investigated possible relationships between the $\mathrm{ABO}$ blood group system and the presence of anti- $T$. gondii antibodies, but their conclusions are conflicting. Four studies reported an association between infection by this parasite and $\mathrm{B}$ and $\mathrm{AB}$ blood groups (5-8). These studies proposed that the $\mathrm{B}$ antigen could act as potential receptor for $T$. gondii. However, two other similar investigations did not find any evidence of this association (9, 10).

The expression of glycoconjugates of the $\mathrm{ABO}$ blood group system occurs in epithelial cells of the gastrointestinal mucosa in approximately $80 \%$ of the population (3). T. gondii utilizes the human gastrointestinal tract (GIT) as one of its infection routes (11). So, the occurrence of these two processes in the same tract and the possible contribution of glycoconjugates in infection 
by $T$. gondii justify the present research (11, 12). Therefore, this study analyzed a possible association between the $\mathrm{ABO}$ blood group system and the presence of anti-Toxoplasma gondii antibodies.

\section{MATERIALS AND METHODS}

\section{Ethical Considerations}

This study was approved by the Research Ethics Committee of the Medical School of São José do Rio Preto (FAMERP - protocol n. 169/2007). Informed consent was considered unnecessary by the Research Ethics Committee since all data were collected from hospital records.

\section{Selection of Hospital Records}

For this descriptive study, the hospital records of 1,120 pregnant women, attended in the Gynecology and Obstetrics Outpatient Clinic of the Base Hospital in São José do Rio Preto, São Paulo state, Brazil, between 2001 and 2004, were analyzed. Of these, 1,006 were selected as they contained complete data and no clinical or laboratory evidence of other medical ailments or infections. This number is sufficient to demonstrate whether there is an association between T. gondii infection and the ABO blood groups with statistical power of more than $90 \%$ as has been previously reported (5).

\section{Data Collection}

Data, such as age, blood type and the result of serological examinations for anti-T. gondii antibodies (only when carried out using the same ELISA technique) were collected from the outpatients' records and noted down on an epidemiological data collection form specifically designed for this study.

\section{Serology Assay}

The serology tests were performed to determine specific IgG and IgM antibodies for T. gondii using a commercial immunoenzymatic assay kit (DiaSorin, Italy). The manufacturers' instructions were precisely followed.

\section{ABO Phenotyping}

The $\mathrm{ABO}$ phenotypes were identified by the standard test tube hemagglutination using commercial monoclonal anti-sera anti-A, anti-B and anti-A,B for direct typing and standard red blood cells $\mathrm{A}_{1}$ and $\mathrm{B}$ for reverse typing (Fresenius Kabi, Brazil).

\section{Statistical Analysis}

The chi-square test and odds ratio were employed to verify any association between the ABO blood group phenotypes and T. gondii infection using the GraphPad Instat ${ }^{\oplus}$ (GraphPad Software Inc., USA) computer program version 3.06. The level of significance was set at $5 \%$ ( $\mathrm{p}$-value $<0.05)$.

\section{RESULTS}

From the total of pregnant women that participated in this study, $79.5 \%(\mathrm{n}=800)$ were Caucasians, $9.9 \%(n=100)$ were mulattoes and $10.5 \%(n=106)$ were Blacks. The mean age was

Table 1. Mean ages and frequencies of the $A B O$ blood group phenotypes in pregnant women with positive and negative serology for lgG and IgM anti-Toxoplasma gondii antibodies, in São José do Rio Preto, Brazil

\begin{tabular}{c|c|c|c|c|c|c|c}
\hline \multirow{2}{*}{ Characteristics } & \multicolumn{2}{|c|}{$\begin{array}{c}\text { Positive } \\
\text { serology }\end{array}$} & \multicolumn{2}{c|}{ Negative serology } & OR & 95\% Cl & p-value \\
\hline Mean age & \multicolumn{2}{|c|}{$26.9 \pm 6.7$} & \multicolumn{2}{|c|}{$25.6 \pm 6.9$} & & & 0.0036 \\
\hline ABO phenotypes & $\mathrm{N}$ & $\%$ & $\mathrm{~N}$ & $\%$ & & & \\
\hline A ( $\mathrm{n}=397)$ & 261 & 40.4 & 136 & 37.7 & 1.124 & $0.8630-1.465$ & 0.42 \\
\hline $\mathrm{B}(\mathrm{n}=113)$ & 76 & 11.8 & 37 & 10.2 & 1.170 & $0.7716-1.773$ & 0.52 \\
\hline AB $(\mathrm{n}=38)$ & 27 & 4.2 & 11 & 3.3 & 1.390 & $0.6811-2.837$ & 0,46 \\
\hline $\mathrm{O}(\mathrm{n}=458)$ & 281 & 43.6 & 177 & 49.0 & 0.802 & $0.6197-1.039$ & 0.10 \\
\hline Total $(\mathrm{n}=1006)$ & 645 & 64.1 & 361 & 35.9 & - & - & - \\
\hline
\end{tabular}


$26.4 \pm 6.7$ years, ranging from 12 to 44 years old. The frequencies of the four $\mathrm{ABO}$ blood group phenotypes, independent of the results of the ELISA, were $39.5 \%(397 / 1006)$ for group A, $11.2 \%(113 / 1006)$ for group $B, 3.8 \%$ (38/1006) for group $\mathrm{AB}$, and $45.5 \%(458 / 1006)$ for group $\mathrm{O}$.

Of the participants, $64.1 \% \quad(645 / 1006)$ presented positive serological results and $35.9 \%$ $(361 / 1006)$ had negative serological results for anti- $T$. gondii antibodies. Of the 645 positive results, $92.2 \%$ (595) were positive only for IgG, $5.0 \%$ (32) were IgG and IgM positive and 2.8\% (18) were positive only for IgM. The mean age of the pregnant women with positive serology $(26.9 \pm 6.7)$ was higher than those with negative serology $(25.6 \pm 6.9)(p$-value $=0.0036)$.

The frequencies of $\mathrm{ABO}$ blood group phenotypes, in respect to results of the serological test (positive [IgG and/or IgM] and negative) for anti-T. gondii antibodies as listed in Table 1, do not demonstrate statistically significant differences $\left(\mathrm{p}\right.$-value $\left.=0.35 ; \chi^{2} 3,255 ; 3 \mathrm{df}\right)$.

\section{DISCUSSION}

In this paper we examined the association between the $\mathrm{ABO}$ blood group system and infection by $T$. gondii in a large cohort of pregnant women without other infections who received medical attention between 2001 and 2004. Since screening for T. gondii antibodies and ABO blood group system phenotyping are compulsory for pregnant women in Brazil, we assembled data from the medical records of women who gave birth in our hospital. The background of the series concerning ethnicity, age and $\mathrm{ABO}$ blood groups is representative of the geographic area in which the study was carried out $(13,14)$.

Although previous studies had demonstrated discordant results, there is a possibility that this parasite utilizes glycoconjugates, which characterize the blood phenotypes of the $\mathrm{ABO}$ blood group system, as potential receptors (510). These glycosylated molecules are expressed in the GIT, which is also utilized as the main route of T. gondii infection (12). Additionally, there is biochemical evidence that several microorganisms utilize glycoconjugates as receptors $(1,2,4)$.

Data obtained from hospital records indicate that the group of individuals selected for this study is representative of the geographical area attended by the Gynecology and Obstetrics Outpatient Clinic. Moreover, the frequencies of positive and negative test results for $T$. gondii are similar to those confirmed in recent investigation performed in the northwestern region of São Paulo state (15).

The mean ages of pregnant women with positive serology tests observed in this study were higher than those with negative results. Most humans tend to produce high avidity IgG anti-T. gondii antibodies, since contact with the infecting forms of $T$. gondii also stimulates the development of immune memory (1621). Additionally, older individuals seem to be exposed to a greater number of stimuli as well as reinfections by this parasite, without necessarily manifesting the clinical form of the disease. Directly proportional relationship between the increase in age and positive serology for IgG anti-T. gondii antibodies has been reported in Cubans and in Czechoslovakians $(6,8,22)$.

It can be assumed that more than $60 \%$ of the pregnant women assessed in this study are possibly immunized and without risk of congenital transmission of T. gondii as shown by the statistically significant differences in mean ages between individuals with positive and negative serology. These observations agree with previous studies that indicate a percentage of IgG anti-T. gondii antibodies in the Brazilian population (20, 23-30).

The present results do not demonstrate any association between evidence of infection by $T$. gondii and the $\mathrm{ABO}$ blood group system and, thus, does not corroborate those studies that propose that the $B$ antigen, expressed in $B$ and $A B$ blood groups, acts as a potential receptor for this parasite in the GIT (5-8). On the other hand, the results agree with investigations of blood donors in Tanzania and of pregnant French women, which did not report any association between this system and infection by $T$. gondii $(9,10)$.

The suggestion that the $\mathrm{B}$ antigen represents a receptor for T. gondii does not appear to be valid for the Brazilian population. The frequencies of the $\mathrm{ABO}$ blood group phenotypes did not present statistically significant differences in the presence or absence of anti-T. gondii antibodies. The expression of glycoconjugates that define $\mathrm{ABO}$ blood group phenotypes also occurs in epithelial cells of the GIT, but their genetic control depends on the presence of at least one functional allele 
of the FUT2 gene (3). This gene codes the $\alpha-2-\mathrm{L}-$ fucosiltransferse enzyme(FUTII), which is capable of incorporating a molecule of fucose to carbon 2 of the galactose terminal of type 1 oligosacharide precursors ( $\mathrm{Gal} \beta 1 \rightarrow 3 \mathrm{GlcNAc} \beta 1 \rightarrow \mathrm{R}$ ) to form type $1 \mathrm{H}$ antigens ([Fuc $1 \rightarrow 2] \mathrm{Gal} \beta 1 \rightarrow 3 \mathrm{GlcNAc} \beta 1 \rightarrow \mathrm{R}$ ). This glycoconjugate, when glycosylated by $\alpha-3$ $\mathrm{D}-\mathrm{N}$-acetilgalactosaminiltransferase or $a-3-\mathrm{D}$ galactosiltransferase enzymes coded by the $A$ and $B$ alleles of the $\mathrm{ABO}$ gene, forms type $1 \mathrm{~A}$ $(\mathrm{NAcGal} \alpha 1 \rightarrow 3$ [Fuca $1 \rightarrow 2$ ] Gal $\beta 1 \rightarrow 3$ GlcNAc $\beta 1 \rightarrow \mathrm{R}$ ) or type 1 B antigens (Gala $1 \rightarrow 3$ [Fuca $1 \rightarrow 2$ ] $\mathrm{Gal} \beta 1 \rightarrow 3 \mathrm{GlcNAc} \beta 1 \rightarrow \mathrm{R})$ respectively $(31,32)$.

All these glycoconjugates are derived from a common precursor, but present variations in their chemical and spatial structural compositions which, apart from differing from those expressed by red blood cells, may be recognized by monoclonal antibodies $(4,31$ 34). However, there is no evidence that these differences influence the susceptibility to $T$. gondii infection, at least when this parasite infects humans by the GIT.

The disagreement among these results and other studies may result from several factors. It is possible that the $\mathrm{B}$ antigen exerts a small influence on the adherence of $T$. gondii to the gastrointestinal mucosa and its contribution is obscured by the high prevalence of infection by these parasites in the Brazilian population, as well as by the molecular variability of its strains identified in Brazilian patients (35-38). Moreover, the use of only female patients in this study and in the one performed in France might not be sufficient to reveal possible influences of gender in the association of the $\mathrm{ABO}$ blood group system with infection by T. gondii (10). In fact, López et al. (6) demonstrated that the $\mathrm{AB}$ group is associated with the presence of IgG anti-T. gondii antibodies in male Cuban blood donors, but their results conflicted with the findings of Midtvedt and Vaage (5) and Kolbekova et al. (8). Infection by $T$. gondii and the expression of antibodies specific to this parasite did not predominantly occur in any one gender (16). Hence, it can be presumed that if anti-T. gondii antibodies are associated with the $\mathrm{ABO}$ blood group system in any populations, it does not depend on gender.

Recently, our group carried out a similar study based on a series of high-risk pregnant women but we did not find evidence of any association (15). This proposition is attractive, since it was demonstrated that in vitro some microorganisms bind to blood carbohydrates including those belonging to the $\mathrm{ABO}$ blood group system (3841). In this previous study, we included the analysis of the G428A mutation of the FUT2 gene which controls the expression of $\mathrm{ABO}$ blood group antigens in the GIT and defines the secretor and non-secretor phenotypes. We did not find any association even when we analyzed $\mathrm{ABO}$ blood group phenotypes and secretor and non-secretor phenotypes isolated and combined in individuals with positive or negative serological tests for IgG and IgM anti-T. gondii antibodies.

We believe that pregnancy, whether low- or high-risk, does not affect the relationship between the ABO blood group system and the humoral immune response against $T$. gondii among Brazilian women. Besides, taking into account the biological cycle of $T$. gondii, it does not infect red blood cells of hosts like other parasites belonging to Apicomplex phylum. However, new studies in other Brazilian regions enrolling different ethnic groups of pregnant women aiming to confirm the lack of association reported in this paper would be very valuable.

\section{CONCLUSIONS}

The ABO blood group system is not associated with the presence or absence of anti- $T$. gondii antibodies in pregnant women in Brazil and, therefore, phenotypic variations resulting from this histo-blood group system do not seem relevant for T. gondii infection.

\section{ACKNOWLEDGEMENTS}

We are thankful to the Medical School of São José do Rio Preto (FAMERP), the National Council for Scientific and Technological Development (CNPq) and the Coordination for the Improvement of Higher Education Personnel (CAPES) for the financial support; and to David Hewitt for English version.

\section{COPYRIGHT \\ (C) CEVAP 2011}

\section{SUBMISSION STATUS}

Received: December 7, 2010.

Accepted: March 1, 2011.

Abstract published online: March 3, 2011.

Full paper published online: May 31, 2011. 


\section{CONFLICTS OF INTEREST}

There is no conflict.

\section{FINANCIAL SOURCE}

BIC FAMERP, BAP-FAMERP, and CNPq (process number 131228/2007-2) provided the financial grants for the present study. Cinara de Cássia Brandão de Mattos received grants from $\mathrm{CNPq}$ and CAPES. Cinara C. B. de Mattos and Lígia C. J. F. Spegiorin are both doctoral students of a health sciences graduate program in FAMERP. Ana Carolina F. Rodrigues, Simone Uezato, Marielle B. Vono and Thiago Pandossio are undergraduate students of the Medical School of São José do Rio Preto who received institutional grants of the Scientific Initiation Program (BIC-FAMERP 2007/2008). Luiz Carlos de Mattos and Lígia C. J. F. Spegiorn received an institutional grant of FAMERP (BAP-FAMERP).

\section{ETHICS COMMITTEE APPROVAL}

The present study was approved by the Research Ethics Committee of the Medical School of São José do Rio Preto (FAMERP), under the protocol number 169/2007.

\section{CORRESPONDENCE TO}

LUIZ CARLOS DE MATTOS, Laboratório de Imunogenética, Departamento de Biologia Molecular, Faculdade de Medicina de São José do Rio Preto, FAMERP, Avenida Brigadeiro Faria Lima, 5416, São José do Rio Preto, SP, 15.090000, Brazil. Phone: +55 17 32015854. Fax: +55 17 32291777. Email: luiz.carlos@famerp.br or imunogenetica.famerp@gmail.com.

\section{REFERENCES}

1. Karlsson KA. Animal glycolipids as attachment sites for microbes. Chem Phys Lipids. 1986;42(1):153-72.

2. Hooper LV, Gordon JI. Glycans as legislators of host-microbial interactions: spanning the spectrum from symbiosis to pathogenicity. Glycobiology. 2001;11(2):1R-10R.

3. Schenkel-Brunner H. Human blood groups - chemical and biochemical basis of antigen specificity. 2nd ed. New York: Springer; 2000. 637 p.

4. Henry SM. Molecular diversity in the biosynthesis of GI tract glycoconjugates. A blood group related chart microorganism receptors. Transf Clin Biol. 2001;8(1):226-30.

5. Midtvedt T, Vaage L. Relationship between Toxoplasma gondii antibodies and blood group. Eur J Clin Microbiol Infect Dis. 1989;8(6):575-6.

6. López R, Fano R, Contreras R, Font L. Anticuerpos
IgG anti-Toxoplasma gondii en Cubanos donantes de sangre. Rev Latinoam Microbiol. 1993;35(1):207-10.

7. Zhiburt EB, Ionova AI, Danil'chenko VV, Serebrianaia NB, Bel'gesov NV, Trofimenko EV. The spread of antibodies to cytomegalovirus and Toxoplasma among donors of blood components. Zh Mikrobiol Epidemiol Immunobiol. 1997;(1):59-61.

8. Kolbekova P, Kourbatova E, Novotna M, Kodym P, Flegr J. New and old risk-factors for Toxoplasma gondii infection: prospective cross-sectional study among military personnel in the Czech Republic. Clin Microbiol Infect. 2007;13(10):12-7.

9. Gill HS. Occurrence of Toxoplasma gondii antibodies in Tanzanian blood donors. East Afr Med J. 1985;62(8):585-8.

10. Lecolier B, Grynberg H, Freund M. Absence of relationship between Toxoplasma gondii antibodies and blood group in pregnant women in France. Eur J Clin Microbiol Infect Dis. 1990;9(2):152-3.

11. Sibley LD. Intracellular parasite invasion strategies. Science. 2004;304(5668):248-53.

12. Carruthers V, Håkansson S, Giddings OK, Sibley D. Toxoplasma gondii uses sulfated proteoglycans for substrate and host cell attachment. Infect Immun. 2000;68(7):4005-11.

13. de Mattos LC, Sanchez FE, Cintra JR, Salles ABCF, Bonini-Domingos CR, Moreira HW. Genotipagem do locus ABO (9q34.1) em doadores de sangue da região noroeste do Estado de São Paulo. Rev Bras Hematol Hemoter. 2001;23(1):15-22.

14. Galão EA, Godoy JMP, Bagarelli LB, Perea LSA, Oliani $\mathrm{AH}$. Epidemiological aspects of the pregnant women with immunodeficiency virus in Brazil. Arch Med Sci. 2007;3(2):142-4.

15. Mattos CCB, Cintra JR, Ferreira AIC, Spegiorin LCJF, Galisteu KJ, Machado RLD, et al. Lack of association between $\mathrm{ABO}$ histo-blood groups, secretor and non-secretor phenotypes, and anti-Toxoplasma gondii antibodies among pregnant women from the northwestern region of São Paulo State, Brazil. Arch Med Sci. 2008;4(3):254-8.

16. Camargo ME. Toxoplasmose. In: Ferreira AW, Ávila SLM. Diagnóstico laboratorial das principais doenças infecciosas e auto-imunes. Rio de Janeiro, RJ: Guanabara Koogan; 2001. 278-88 p.

17. Frank SA. Immunology and evolution of infectious disease. New Jersey: Princeton University Press; 2002. $348 \mathrm{p}$.

18. Reis MM, Tessaro MM, D’azevedo PA. ToxoplasmaIgM and IgG-avidity in single samples from areas with a high infection rate can determine the risk of motherto-child transmission. Rev Inst Med Trop S Paulo. 2006;48(2):93-8.

19. Araújo PRB, Ferreira AW. Avidity of IgG antibodies against excreted/secreted antigens of Toxoplasma gondii: immunological marker for acute toxoplasmosis. Rev Soc Bras Med Trop. 2008;41(2):142-7.

20. Leite M, Siciliano S, Rocha LSA, Justa MTR, César KR, Granato CF. Correlation between specific IgM levels and percentage IgG-class antibody avidity 
to Toxoplasma gondii. Rev Inst Med Trop S Paulo. 2008;50(4):237-42.

21. Miller CM, Boulter NR, Ikin RJ, Smith NC. The immunobiology of the innate response to Toxoplasma gondii. Int J Parasitol. 2008;39(1):23-39.

22. Martín-Hernándes I, García-Izquierdo SM. Prevalencia de anticuerpos IgG contra Toxoplasma gondii en donantes de sangre cubanos. Rev Biomed. 2003;14(1):247-51.

23. Vaz AJ, Guerra EM, Ferrato LCC, de Toledo LAS, Azevedo Neto RS. Positive serology of syphilis, toxoplasmosis and Chagas' disease in pregnant women in their first visit to health centers in a metropolitan area, Brazil. Rev Saude Públ. 1990;24(5):373-9.

24. Cerqueira RL, Kawarabayashi M, Guimarães AC, Nakamura PM, Ferraz SN, Pinto PL et al. Santo Inacio revisited: protozoan diseases in an isolated village in northeastern Brazil after twenty years. Am J Trop Med Hyg. 1998;59:736-40.

25. Rey LC, Ramalho ILC. Seroprevalence of toxoplasmosis in Fortaleza, Ceará, Brazil. Rev Inst Med Trop S Paulo. 1999;41(3):171-4.

26. Coêlho RAL, Kobayashi M, Carvalho Jr LB. Prevalence of IgG antibodies specific to Toxoplasma gondii among blood donors in Recife, Northeast Brazil. Rev Inst Med Trop S Paulo. 2003;45(4):229-31

27. Francisco FM, Souza SLP, Gennari SM, Pineiro SR, Muradian V, Soares RM. Seroprevalence of toxoplasmosis in a low-income community in the São Paulo municipality, SP, Brazil. Rev Inst Med Trop S Paulo. 2006;48(3):167-70.

28. Figueiró-Filho EA, Senefonte FRA, Lopes AHA, Morais OO, Souza Júnior VG, Maia TL et al. Freqüência das infecções pelo HIV-1, rubéola, sífilis, toxoplasmose, citomegalovírus, herpes simples, hepatite $\mathrm{B}$, hepatite C, doença de Chagas e HTLV I/II em gestantes, do Estado do Mato Grosso do Sul. Rev Soc Bras Med Trop. 2007;40(2):181-7.

29. Carellos EVM, Andrade GMQ, Aguiar RALP. Avaliação da aplicação do protocolo de triagem prénatal para toxoplasmose em Belo Horizonte, Minas Gerais, Brasil: estudo transversal em puérperas de duas maternidades. Cad Saúde Pública. 2008;24(2):391401.

30. Porto AMF, Amorim MMR, Coelho ICN, Santos LC. Serologic profile of toxoplasmosis in pregnant women attended at a teaching-hospital in Recife. Rev Assoc Med Bras. 2008;54(3):242-8.
31. Oriol R. ABO, Hh, Lewis and secretion: serology, genetics and tissue distribution. In: Cartron JP, Rouger P, editors. Blood cell biochemistry: molecular basis of human blood group antigens. New York: Plenum; 1995. p. 37-73.

32. Henry SM, Samuelsson B. ABO polymorphisms and their putative biological relationships with disease. In: King MJ, editor. Human blood cells: consequences of genetic polymorphisms and variations. Singapore: Imperial College Press; 2000. p. 15-103.

33. Angstrom J, Larsson T, Hansson GC, Karlsson KA, Henry S. Default biosynthesis pathway for blood group-related glycolipids in human small intestine as defined by structural identification of linear and branched glycosilceramides in a group $\mathrm{O}$ Le(a-b-) nonsecretor. Glycobiology. 2004;14(1):1-12.

34. Svensson L, Rydberg L, de Mattos LC, Henry SM. Blood group A1 and A2 revisited: an immunochemical analysis. Vox Sang. 2009;96(1):56-61.

35. Colombo FA, Vidal JE, Penalva de Oliveira AC, Hernandez AV, Bonasser-Filho F, Nogueira RS et al. Diagnosis of cerebral toxoplasmosis in AIDS patients in Brazil: importance of molecular and immunological methods using peripheral blood samples. J Clinic Microbiol. 2005;43(10):5044-7.

36. Khan A, Jordan C, Muccioli C, Vallochi AL, Rizzo LV, Belfort Jr R et al. Genetic divergence of Toxoplasma gondii strains associated with ocular toxoplasmosis. Emerg Infect Dis. 2006;12(6):942-9.

37. Ferreira IMR, Vidal JE, Costa-Silva TA, Meira CS, Hiramoto RM, Penalva de Oliveira AC, et al. Toxoplasma gondii: genotyping of strains from Brazilian AIDS patients with cerebral toxoplasmosis by multilocus PCR-RFLP markers. Exp Parasitol. 2008;118(2):221-7.

38. Imberty A, Varrot A. Microbial recognition of human cell surface glycoconjugates. Curr Opin Struct Biol. 2008;18(5):567-76.

39. Boulanger MJ, Tonkin ML, Crawford J. Apicomplexan parasite adhesins: novel strategies for targeting host cell carbohydrates. Curr Opin Struct Biol. 2010;20(5):551-9.

40. Anstee DJ. The relationship between blood groups and disease. Blood. 2010;115(23):4635-43.

41. Mattos DE, Cintra JR, Brandão de Mattos CC, Nakashima F, Silva RCMA, Moreira HW et al . ABO blood groups and Helicobacter pylori cagA infection: evidence of an association. J Venom Anim Toxins incl Trop Dis. 2010;16(1):87-95. 